\title{
30. 鼓室成形術前後の語音聴力
}

\author{
滝本 勲・○稲福 繁・山田一美（名大）
}

鼓室成形術における語音聴力の推移を検討した報告は 少なく，特に最近広く行われている外耳道保存一筋膜使 用例については新たな検討を要すと思われる，今回われ われは最近行われた鼓室成形術例について検討して見 た. 症例は全て新鮮手術例で術式は外耳道保存・筋膜単 独使用例であり，術後内耳障害をきたした 2 例や再穿孔 をきたし Sound protection に難のある 2 症例恰外し てある、なお，鼓膜形成材料の種類や術型による手術成 績の検討は滝本らの報告があるので，今回は術前後にお ける純音域値の変動と語音聴力の推移に限つて検討し, 又一部はその遠隔成績について報告した。なお，32耳中 Wullstein I 型は 13 耳, W-II型 ( 2 耳), W-III型 (14 耳) W-IV型 ( 3 耳) である.

結果 : Social Hearing Level の内外を問わず, 術後聴 力 $(0.5 ， 1 ， 2 ， 4 \mathrm{kHz}$ 平均) が $10 \mathrm{~dB}$ を越えて上㫒した 例は 3 例あり, 語音聴力む平行して上昇している。 これ らは tymp III型又は III型 Mod であつたが従来の open method Skin grafting と著明な差は見られない，上昇 傾向 $(+5 \sim+10 \mathrm{~dB})$ は 5 例あり, これらは全体として 語音聴力も上昇傾向を認めるが変化してない症例もみら れる. 又術前後純音聴力で変化のなかつた群は Social Hearing Level 内が 7 例, Level 以下が 5 例であるが, この群ならびに純音聴力低下傾向群 $(-5 \sim-10 \mathrm{~dB}) 5$ 耳についても，語音聴力はさほど変動してない，今回特 に注目したのは術後聴力が悪化した群 8 耳についての詳 細な症例の検討とその遠隔成績である。8例中 4 例は術 後 3 力月より10カ月の閒で缌力は著明に改善し, 術前の 域値に近くなっているのが見られ，これらの局所所見 は，退院時に鼓膜が厚かつたり，又一部未上皮化のまま 術後聴検を行ない退院後上皮化完了と, その後鼓膜の菲 薄化が見られ，症例によつてはうすく Incudostapedial
純音聴力変化（術前後の差）と語音曲線

\begin{tabular}{|c|c|c|c|}
\hline \multirow{2}{*}{$\begin{array}{l}\text { 純 音聴力変 化 } \\
\text { (0. } 5,1,2, \quad 4 \mathrm{kHz} \\
\text { 平均) }\end{array}$} & \multicolumn{3}{|c|}{ 語 音 検 查 } \\
\hline & 上昇 & 不 変 & 悪 化 \\
\hline $\begin{array}{l}+10 \mathrm{~dB} \text { 以上 } \\
\text { 改 善 }\end{array}$ & 3 & 0 & 0 \\
\hline $\begin{array}{l}+5 \sim+10 \mathrm{~dB} \\
\text { 改善傾向 }\end{array}$ & 3 & 1 & 0 \\
\hline $\begin{array}{c}-5 \sim+5 \mathrm{~dB} \\
\text { 不 变 }\end{array}$ & 0 & 12 & 0 \\
\hline $\begin{array}{l}-5 \sim-10 \mathrm{~dB} \\
\text { 悪化傾向 }\end{array}$ & 0 & 4 & 1 \\
\hline $\begin{array}{l}-10 \mathrm{~dB} \text { 以上 } \\
\text { 悪 化 }\end{array}$ & 0 & 1 & 7 \\
\hline
\end{tabular}

Joint か゚すけてみえる症例もあつた。このことより筋膜 移植をした例では，その術後成績の検討では比較的長期 的にその経過を観察し判断しなければならないと考え る。遠隔成績で聴力が悪化した例が一例あつたが，いわ ゆる浅在化や再穿孔形成・療着等は認められない事実か らして，理由は更に検討を必要とするが， transformation がうまく行かなかつたものである. 又一部に周波数 により上昇部分と下降部分のあつた例むあるが，多くの 場合術後 1 力月の聴力が，そのまま保持されており，語 音聴力む同様である。これは筋膜（鼓膜）が厚い状態で 経過してむ聴力は保持されていることを示し注目すべき ことである. 結論として 1) 語音聴力は純音聴力の推 移と平行して例が多い 2）筋膜による鼓膜形成例は， その術後聴力については比較的長期の観察を要し, 少な からぬ率で聴力変動を呈す例が出てくる. 